Article

\title{
Croton argyrophyllus Kunth Essential Oil-Loaded Solid Lipid Nanoparticles: Evaluation of Release Profile, Antioxidant Activity and Cytotoxicity in a Neuroblastoma Cell Line
}

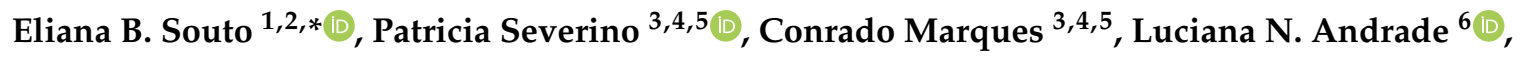 \\ Alessandra Durazzo ${ }^{7}$ (D), Massimo Lucarini ${ }^{7}$, Atanas G. Atanasov ${ }^{8,9,10,11}$ (D), \\ Soukaina El Maimouni ${ }^{12}$, Ettore Novellino ${ }^{12}$ and Antonello Santini ${ }^{12, * \mathbb{D}}$ \\ 1 Department of Pharmaceutical Technology, Faculty of Pharmacy, University of Coimbra (FFUC), \\ Pólo das Ciências da Saúde, Azinhaga de Santa Comba, 3000-548 Coimbra, Portugal \\ 2 CEB-Centre of Biological Engineering, University of Minho, Campus de Gualtar, 4710-057 Braga, Portugal \\ 3 Laboratory of Nanotechnology and Nanomedicine (LNMED), Institute of Technology and Research (ITP), \\ Av. Murilo Dantas, 300, Aracaju 49010-390, Brazil; pattypharma@gmail.com (P.S.); \\ conrado.marques@souunit.com.br (C.M.) \\ 4 Industrial Biotechnology Program, University of Tiradentes (UNIT), Av. Murilo Dantas 300, \\ Aracaju 49032-490, Brazil \\ 5 Tiradentes Institute, 150 Mt Vernon St, Dorchester, MA 02125, USA \\ 6 Department of Physiology, Federal University of Sergipe, São Cristóvão 49100-000, Brazil; \\ luciana.nalone@hotmail.com \\ 7 CREA-Research Centre for Food and Nutrition, Via Ardeatina 546, 00178 Rome, Italy; \\ alessandra.durazzo@crea.gov.it (A.D.); massimo.lucarini@crea.gov.it (M.L.) \\ 8 Institute of Neurobiology, Bulgarian Academy of Sciences, 23 Acad. G. Bonchev str., 1113 Sofia, Bulgaria; \\ atanas.atanasov@univie.ac.at \\ 9 Institute of Genetics and Animal Biotechnology, Polish Academy of Sciences, Jastrzębiec, \\ 05-552 Magdalenka, Poland \\ 10 Department of Pharmacognosy, University of Vienna, Althanstraße 14, 1090 Vienna, Austria \\ 11 Ludwig Boltzmann Institute for Digital Health and Patient Safety, Medical University of Vienna, \\ Spitalgasse 23, 1090 Vienna, Austria \\ 12 Department of Pharmacy, University of Napoli Federico II, Via. D. Montesano 49, 80131 Napoli, Italy; \\ soukainaelmaimouni@gmail.com (S.E.M.); ettore.novellino@unina.it (E.N.) \\ * Correspondence: ebsouto@ff.uc.pt or souto.eliana@gmail.com (E.B.S.); asantini@unina.it (A.S.); \\ Tel.: +351-239-488-400 (E.B.S.); +39-081-253-9317 (A.S.)
}

Received: 7 August 2020; Accepted: 16 September 2020; Published: 17 September 2020

\begin{abstract}
The essential oil from Croton argyrophyllus Kunth is known for its antiproliferative, anti-inflammatory, antinociceptive, and anticancer activities, and is recognized as a source of phytochemicals for potential use in pharmaceutic and food sectors. Solid lipid nanoparticles (SLN) have been produced to load Croton argyrophyllus $(C A)$ Kunth essential oil ( $\left.{ }_{\mathrm{CA}} \mathrm{EO}\right)$ and its antioxidant properties evaluated in vitro as a new approach for the treatment of neurodegenerative diseases. Cetyl palmitate SLN loading ${ }_{\mathrm{CA}} \mathrm{EO}$ (CA EO-SLN) with a mean particle size of $201.4 \pm 2.3 \mathrm{~nm}$ (polydispersity index 0.211 ) have been produced by hot high-pressure homogenisation. The release of the oil followed the Korsmeyers-Peppas model. The risk of lipid peroxidation has been determined by applying the production of thiobarbituric acid-reactive substances (TBARS) standard assay. The antioxidant activity was determined by the capacity of the antioxidants existing in ${ }_{\mathrm{CA}} \mathrm{EO}$ to scavenge the stable radical DPPH•. The cytotoxicity of CA Kunth essential oil-loaded SLN (CAEO-SLN) was evaluated in a human cell line SH-SY5Y (derived from human neuroblastoma) by determining the reduction of the yellow dye 3-(4,5-dimethyl-2-thiazolyl)-2,5-diphenyl-2H-tetrazolium bromide (MTT). Both free essential oil $(f \mathrm{EO})$ and loaded essential oil (CAEO-SLN) were demonstrated to inhibit the Fenton
\end{abstract}


reaction. ${ }_{\mathrm{CA}} \mathrm{EO}-\mathrm{SLN}$ showed DPPH• radical scavenging capacity. The loading of the oil into cetyl palmitate SLN reduced the risk of cytotoxicity.

Keywords: antioxidant; cytotoxic; essential oil; Croton argyrophyllus Kunth; neurological disorders

\section{Introduction}

Antiproliferative, anti-inflammatory, antinociceptive, anticancer, and antioxidant properties have been attributed to the essential oils of several Croton species [1-3]. Essential oils are a combination of terpenes and other secondary metabolites, which together show beneficial effects both in humans and in animals [4-7]. Compounds belonging to terpenoids class may show cytotoxic, antitumor and antibacterial activity $[8,9]$, while a combination of the antioxidant activity with cytotoxic and antitumoral effects was shown to be instrumental to explain the interest of essential oils for pharmaceutical and nutraceutical applications $[10,11]$. Because of their chemical composition, essential oils from other species have shown cytotoxic activities in a variety of cell lines [12,13].

Croton argyrophyllus is commonly known and has been used in traditional medicine for centuries [14]. The insecticidal activity of the essential oil has already been described, for which the average lethal concentration was found to be below the one needed to promote acute toxicity in a typical mouse model [6]. Its anti-inflammatory activity was also described in Wistar rats, as shown by a significant inhibition of paw edema formation and leukocyte influx induced by $1 \%$ carrageenan solution [15]. The recent work published by de Araújo et al. (2019) [16], by studying the properties of the inner bark of Croton argyrophyllus (Euphorbiaceae), reported how hydroethanolic extract can partially reduce the biomarkers of oxidative stress in muscle tissue, and thus muscular damage in rats that were submitted to high intensity strength exercise [16]. The antioxidant properties represent the first stage of evaluation of health properties of food matrices and result from the combination of bioactive compounds [17-19], thereby attracting high scientific interest [20].

The neuroprotective and anti-aging properties of essential oils derived from various sources have been attributed to their complex composition [21-26]. These have an essential role in the protection of their plant species by acting against, e.g., invasive microorganisms and herbivores, while attracting insects to act as pollinizing vectors [27]. Besides, Mediterranean diet, which is also rich in essential oils, has long been recognized to have beneficial effects against ageing [28]. The main studies on the chemical composition of essential oils, oil extraction methodologies, and their interest for therapeutic uses are comprehensively discussed by Aziz et al. (2018) [29]. Valdivieso-Ugarte et al. (2019) have also described relevant antimicrobial, immunomodulatory, and antioxidant properties of essential oils [30]. Essential oils are however volatile and have limited chemical stability over shelf life. Their physicochemical stability can be improved by their loading into nanoparticles [31,32]. Lipid nanoparticles were tested for brain targeting of drugs in the management of several neurological disorders, thanks to their biocompatibility, affinity to the blood-brain-barrier, and high payload for lipophilic bioactives [33-36]. The loading of a variety of essential oils into nanoparticles has been proposed as a strategy to modify the cytotoxic profile of these complex mixtures, increase their bioavailability, and improve their therapeutic outcomes in vivo [22,37-39]. In the present work, we have thoroughly characterized the release, antioxidant, and cytotoxic profiles of the essential oil obtained from the leaves of Croton argyrophyllus Kunth when loaded in cetyl palmitate solid lipid nanoparticles (SLN).

\section{Material and Methods}

\subsection{Materials}

The leaves of Croton argyrophyllus Kunth were obtained from the region of Alagoas, Brazil-the freshly collected plant was subject to hydrodistillation in a Clevenger apparatus for a period of $3 \mathrm{~h}$. Then, 
the obtained oil was dried using anhydrous sodium sulfate and was stored at $-5^{\circ} \mathrm{C}$ for further analysis. Cetyl palmitate was given as a gift from Croda do Brasil Ltda (Campinas, Brazil). Thiobarbituric acid (TBA), butylated hydroxytoluene (BHT), Trolox, Poloxamer ${ }^{\circledR} 407,3-(4,5-d i m e t h y l-2-t h i a z o l y l)-$ 2,5-diphenyl-2H-tetrazolium bromide (MTT), doxorubicin(purity > 98\%), Dulbecco's modified Eagle's medium (DMEM), dimethyl sulfoxide (DMSO), foetal bovine serum (FBS), L-glutamine, streptomycin, and penicillin, were acquired from Sigma Chemical Co. (St. Louis, MO, USA). Double-distilled water was obtained from filtration in a Millipore system (home supplied).

\subsection{Production of Solid Lipid Nanoparticles}

SLNs were produced by hot high-pressure homogenization; cetyl palmitate was used as solid lipid and Poloxamer ${ }^{\circledR} 407$ as surfactant. In brief, the melted lipid phase, composed of cetyl palmitate [4.5\% $(w / v)]$ and Croton argyrophyllus Kunth essential oil [0.5\% $(w / v)]$, was dispersed in an aqueous phase made up of MilliQ water [94.525\% (w/v)] and Poloxamer ${ }^{\circledR} 407$ [0.950\% $\left.(w / v)\right]$, heated at $70{ }^{\circ} \mathrm{C}$. A pre-emulsion was obtained by stirring the mixture at $8000 \mathrm{rpm}$ for $30 \mathrm{~s}$ in an Ultra-Turrax (Ultra-Turrax ${ }^{\circledR}$, T25, IKA, Staufen, Germany). Then, it was processed in a high-pressure homogeniser (EmulsiFlex ${ }^{\circledR}-\mathrm{C} 3$, Avestin, Ottawa, ON, Canada) (previously heated by recirculating hot Milli-Q water at $75 \pm 0.5^{\circ} \mathrm{C}$ ), for $5 \mathrm{~min}$, at 500 bars in the first cycle and at 60 bars in the second cycle. The produced $o / w$ nanoemulsion, after $5 \mathrm{~min}$ in the homogeniser, was placed into siliconized glass vials and cooled down in the fridge $\left(4 \pm 0.5^{\circ} \mathrm{C}\right)$ to produce SLN. Plain SLN were produced as described, using cetyl palmitate $[5.0 \%(w / v)]$ as solid matrix (without the loading of the essential oil).

\subsection{Mean Particle Size and Polydispersity Index}

Dynamic light scattering (DLS) in a Zetasizer Nano ZS (Malvern, Worcestershire, UK) was utilized to measure the polydispersity index (PI) and mean particle size (z-Ave) immediately after production. Dilution in MilliQ water by 100 times of the aqueous dispersions of SLN was carried out, and the analyses we carried out in triplicate measurements $(n=3)$. Data are given as means \pm standard deviations (SD).

\subsection{Encapsulation Efficiency (EE) and Loading Capacity (LC)}

The particles were ultra-centrifuged (Beckman Optima ${ }^{\mathrm{TM}}$ Ultracentrifuge-Optima ${ }^{\mathrm{TM}} \mathrm{XL}$, Indianapolis, IN, USA) for $1 \mathrm{~h}$ at $100,000 \times \mathrm{g}$. The alpha-pinene, one of the main bioactive compounds of C. argyrophyllus [14], was evaluated in the supernatant throughout UV spectrophotometer Shimadzu UV-1601 (Shimadzu Italy, Cornaredo, Italy) at $230 \mathrm{~nm}$ [40], and the encapsulation efficiency (EE) and loading capacity $(L C)$ were evaluated using the following equations [41]:

$$
\begin{gathered}
E E \%=\frac{W a-W s}{W a} \times 100 \\
L C \%=\frac{W a-W s}{W a-W s+W_{L}} \times 100
\end{gathered}
$$

where $W a$ is the mass of essential oil (i.e., as a measure of the alpha-pinene) utilized for the development of SLN, $W_{L}$ is the mass of lipid added for the development of SLN, and Ws is the mass of essential oil quantified in the supernatant.

\subsection{Differential Scanning Calorimetry}

The DSC (DSC Q20 TA Instruments, New Castle, DE, USA) was utilized to determine the degree of crystallinity of the non-loaded SLN (plain) and loaded SLN (CA EO-SLN). Briefly, the samples were weighted (about 3-5 mg) in an aluminium pan and then sealed hermetically. The samples were analysed under inert atmosphere $\left(45 \mathrm{~mL} / \mathrm{min}\right.$ of $\left.\mathrm{N}_{2}\right)$. The DSC thermograms were recorded in the first 
heating run at a constant rate of $10^{\circ} \mathrm{C} / \mathrm{min}$ within a range of temperatures of $25-85^{\circ} \mathrm{C}$. The crystallinity index $(\mathrm{CI} \%)$ was calculated as follows [42]:

$$
\mathrm{CI} \%=\frac{\Delta H_{S L N}}{\Delta H_{\text {Bulk Material }} \times \text { Concentration }_{\text {Lipid Phase }}} \times 100
$$

\subsection{In Vitro Release of $\mathrm{CA}^{E O-S L N}$}

The Franz glass diffusion cells was utilized to evaluate the in vitro release of Croton argyrophyllus Kunth essential oil from SLN. Previously, a cellulose membrane (MERCK KgaA) (average pore size: $0.22 \mu \mathrm{m}$ ) was soaked for $2 \mathrm{~h}$ in freshly prepared phosphate-buffered saline (PBS, $\mathrm{pH}$ 7.4), and then it was inserted in between the donor and acceptor chambers. Briefly, $1 \mathrm{~mL}$ of ${ }_{\mathrm{CA}}$ EO-SLN (freshly prepared) was inserted onto the hydrated cellulose membrane. The acceptor chamber, that contains $5 \mathrm{~mL}$ of PBS buffer, was maintain under magnetic stirring at $37^{\circ} \mathrm{C}$ along the entire assay. At selected time-intervals, $200 \mu \mathrm{L}$ were sampled with a syringe, being the same volume replaced with PBS buffer to keep the sink conditions over the course of the experiment. The amount of released essential oil was determined using a UV spectrophotometer Shimadzu UV-1601 (Shimadzu Italy, Cornaredo, Italy) at $230 \mathrm{~nm}$ for the quantification of alpha-pinene. Two kinetic models, i.e., Higuchi and Korsmeyer-Peppas, were tested based on the obtained $\mathrm{R}^{2}$ values for the mathematical fitting of the recorded values [43].

\subsection{In Vitro Lipid Peroxidation Assay}

A mixture of $1 \mathrm{~mL}$ of egg yolk homogenate $(1 \% w / v)$ in phosphate buffer $(\mathrm{pH} 7.4)$ was treated with $0.1 \mathrm{~mL}$ ferrous sulphate $\left(\mathrm{FeSO}_{4}, 0.17 \mathrm{~mol} / \mathrm{L}\right)$, with the increase of concentrations ${ }_{\mathrm{CA}} \mathrm{EO}-\mathrm{SLN}(5,10$ and $20 \mu \mathrm{g} / \mathrm{mL}$ ). Trolox (antioxidant compound as standard) at $50 \mu \mathrm{g} / \mathrm{mL}$ was utilized as positive control and water as the negative control. The mixture was then incubated for $30 \mathrm{~min}$ at $37^{\circ} \mathrm{C}$. Upon cooling, $0.5 \mathrm{~mL} / \mathrm{sample}$ and $0.5 \mathrm{~mL}$ of trichloroacetic acid solution $(15 \% \mathrm{~m} / \mathrm{v})$ were centrifuged at $1200 \mathrm{rpm}$ for $10 \mathrm{~min} .0 .5 \mathrm{~mL}$ of supernatant were collected and mixed with the $0.5 \mathrm{~mL}$ of thiobarbituric acid solution $(0.67 \% \mathrm{~m} / \mathrm{v})$, and then incubated for $60 \mathrm{~min}$ at $95^{\circ} \mathrm{C}$. After cooling, TBARS was spectrophotometrically determined throughout the measure of the supernatant at $532 \mathrm{~nm}$, and the results were given as malondialdehyde equivalents (MDA Eq) of the substrate.

\subsection{In Vitro Antioxidant Activity against Free Radical DPPH}

The antioxidant activity was determined as the ability of the antioxidants present in the sample test to scavenge the stable radical DPPH• [44]. A $0.1 \mu \mathrm{M}$ DPPH methanolic solution was firstly prepared to dissolve the sample test, which was then placed in the microplate wells. DPPH solution was added to each of the wells to reach concentrations $(1,2,3,4,5$ and $10 \mu \mathrm{g} / \mathrm{mL})$ of essential oil. Methanol was utilized as negative control, whereas butylated hydroxytoluene (BHT, $0-6 \mu \mathrm{g} / \mathrm{mL}$ ) was positive control. Then, incubation in microplates was carried out at $25^{\circ} \mathrm{C}$ for $30 \mathrm{~min}$, and the absorbance was determined in a multiplate reader (DTX 880 Multimode Detector, Beckman Coulter Inc., Brea, CA, USA) at $517 \mathrm{~nm}$. The antioxidant activity, expressed as the percentage of scavenging of DPPH, was determined using the following equation:

$$
\text { Scavenging of DPPH }(\%)=\frac{\text { Optical density of negative control }- \text { Optical density of test sample }}{\text { Optical density of negative control }} \times 100
$$

The $\mathrm{IC}_{50}$ values were determined using linear regression $\left(\mathrm{r}^{2}=0.971\right)$ by plotting the percentage of scavenging the concentration in the $X$-axis $(\mu \mathrm{g} / \mathrm{mL})$ and the $(\%$ inhibition in the $Y$-axis, recorded at the end of the assay.

\subsection{Cell Culture and Cytotoxicity Assay}

SH-SY5Y (derived from human neuroblastoma) cell line was given from ATCC (Pensabio Biotecnologia, São Paulo, Brazil). Cells were grown in Dulbecco's modified Eagle's medium (DMEM) 
supplemented with $10 \%(v / v)$ foetal bovine serum (FBS), $100 \mathrm{U} / \mathrm{mL}$ penicillin, $100 \mu \mathrm{g} / \mathrm{mL}$ streptomycin, and $1 \mathrm{mM}$ L-glutamine. Cells were kept at $37{ }^{\circ} \mathrm{C}$ and $5 \% \mathrm{CO}_{2} / 95 \%$ air environment. The viability of SH-SY5Y cell line when treated with ${ }_{\mathrm{CA}} \mathrm{EO}-\mathrm{SLN}$ was determined by the reduction of the yellow dye 3-(4,5-dimethyl-2-thiazolyl)-2,5-diphenyl-2H-tetrazolium bromide (MTT) to a blue formazan product $[35,36]$. Cells were seeded in 96-well plates $0.1 \times 10^{6}$ cells $/ \mathrm{mL}$ density. After $24 \mathrm{~h}, \mathrm{CA}$ EO-SLN $(0-20 \mu \mathrm{g} / \mathrm{mL})$, dissolved in $0.7 \%$ dimethyl sulfoxide (DMSO), was added to each well. Then, the cells were subject to incubation for $72 \mathrm{~h}$ at $37{ }^{\circ} \mathrm{C}$ in a $5 \% \mathrm{CO}_{2}$ atmosphere. The analyses were carried out as three independent experiments, using DMSO at $1 \%$ was used as negative control and doxorubicin at $100 \mu \mathrm{g} / \mathrm{mL}$ as positive controls. Then incubation, the plates were centrifuged, and the medium was replaced by fresh medium $(150 \mu \mathrm{L})$ containing $0.5 \mathrm{mg} / \mathrm{mL}$ MTT. Three hours later, the formazan product was dissolved in $150 \mu \mathrm{L} \mathrm{DMSO}$, and absorbance was read in a multiplate reader (DTX 880 Multimode Detector, Beckman Coulter Inc.) at $570 \mathrm{~nm}$. The tests were carried out in quadruplicate and then normalized. Percentage of cell viability was calculated as follows:

$$
\% \text { Cell viability }=\frac{\text { Abs (treated cells })- \text { Abs (blank })}{\text { Abs (positive control })- \text { Abs (blank })} \times 100
$$

\subsection{Statistical Analysis}

The results are given as the mean \pm standard error of mean (SEM). Statistical significance of differences between mean values was determined by ANOVA with Dunnet post-test. Results were considered significantly different if $p<0.05$. Graphs and statistical evaluation were performed by means of the GraphPad Prism software (Intuitive Software for Science, San Diego, CA, USA). An asterisk (*) has been used to spot the results that are significantly different from control.

\section{Results and Discussion}

The loading of the lipophilic essential oil obtained from Croton argyrophyllus Kunth in cetyl palmitate SLN resulted in particles with a mean size of $201.4 \pm 2.3 \mathrm{~nm}$ (polydispersity index 0.211), against plain SLN (oil-free) of $228 \pm 1.6 \mathrm{~nm}$ and PI of 0.242 . From the recorded values, both plain and oil-loaded SLN are expected to show long-term stability on shelf-life with limited risk of aggregation. According to the literature, a PI below 0.25 translates a monodispersed system, ensures a higher physical stability of colloidal dispersions, and is suitable for biomedical applications [45]. The loading capacity (LC\%) (EE\%) and encapsulation efficiency achieved $0.43 \pm 0.07 \%$ and $89.63 \pm 1.02 \%$, respectively. These high values were related to the high affinity of essential oil to the solid lipid. For both ${ }_{C A}$ EO-SLN and oil-free SLN, the melting peaks were revealed in the bulk lipid melting range. The loading of the oil resulted in the decrease of degree of crystallinity (such as lower melting enthalpy), i.e., $81 \%$ (oil-free SLN) versus $76 \%$ (CAEO-SLN). This suggest how the formation of a metastable polymorphic matrix ( $\beta^{\prime}$-modification) could be due to a higher loading capacity, and is characteristic of acetyl palmitate SLN, with respect to the more stable one ( $\beta$-modification) [46]. The presence of a crystalline solid matrix in ${ }_{C A} E O-S L N$ contributed to modify the release profile of the essential oil. As reported in Figure 1 (upper panel), less than $10 \%$ of loaded essential oil was released within the first two hours, which lead to a delayed release. By the end of $24 \mathrm{~h}$ ca., $70 \%$ of loaded oil was quantified in the receiving medium of Franz diffusion cells. Mathematical fitting of the release data was developed throughout the Higuchi and Korsmeyer-Peppas equations (Figure 1) [47].

On the basis of the $\mathrm{R}^{2}$ values, the Korsmeyers-Peppas model was the best fitting one. A release profile following the Higuchi model (Fickian diffusion) implies a straight line with $k_{H}$ as slope will be obtained when plotting $\mathrm{x}=k_{H}$ against $\mathrm{y}=M_{t} / M_{\infty}$. In the present study, a $\mathrm{R}^{2}$ of 0.8677 was obtained, which means no straight line was drawn with the recorded values. Korsmeyers-Peppas model (Power Law) describes the release of the loaded active/oil from the nanoparticles accordingly to the following mechanism: $M_{t} / M_{\infty}=k^{\prime} t^{n}$, where $M_{t}$ is the cumulative amount of active released at time $t, M_{\infty}$ is the cumulative amount of active released at infinite time, $k^{\prime}$ is the constant that is 
governed by the physicochemical properties of the core of the nanoparticles, and $n$ is the diffusional release exponent indicating of the release mechanism of the loaded ingredient from the particles [48].
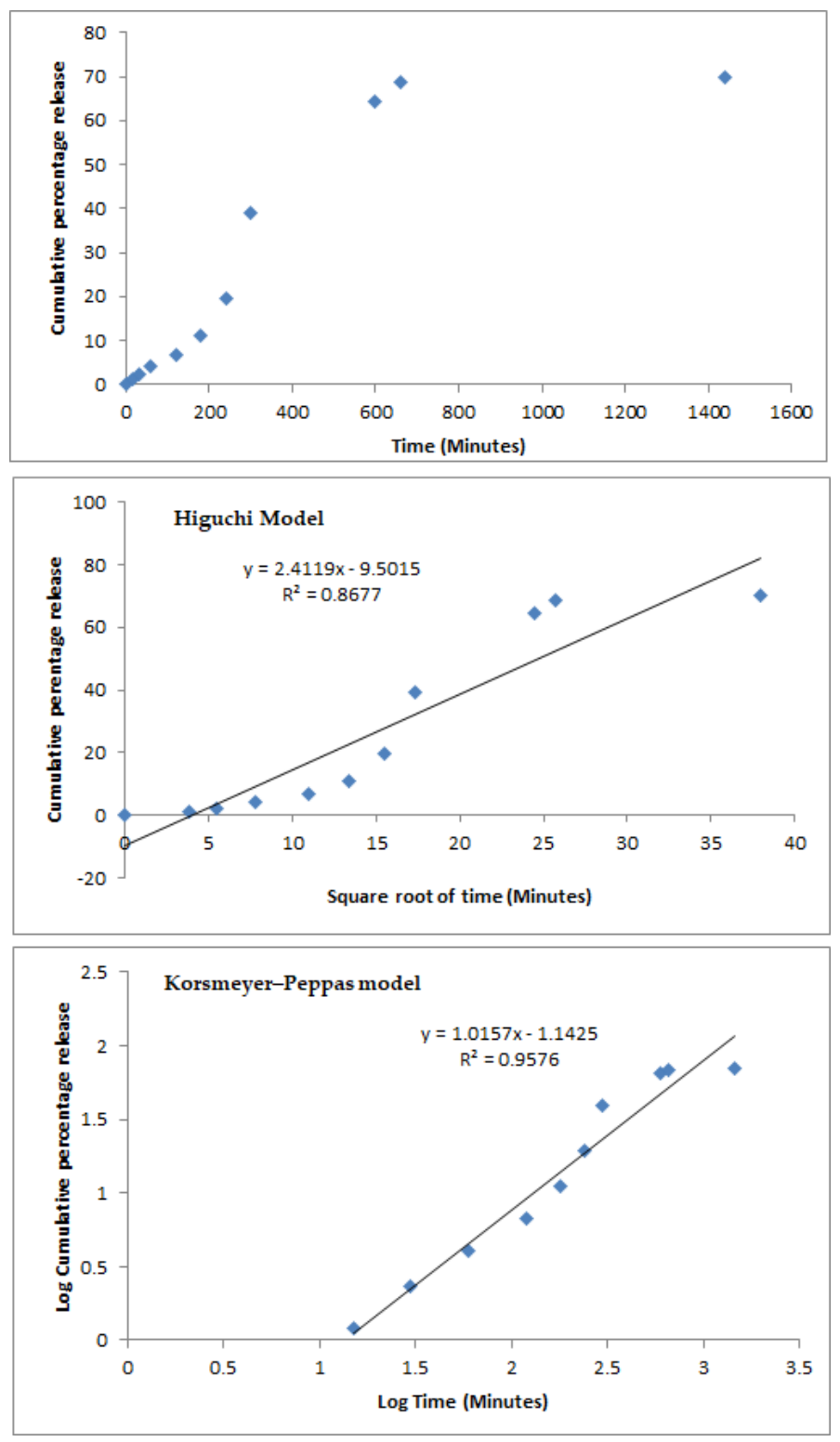

Figure 1. Cumulative percentage release of Croton argyrophyllus Kunth essential oil from cetyl palmitate solid lipid nanoparticles (SLN) (upper), and its mathematical fitting using the Higuchi (middle) and Korsemeyer-Peppas (lower) models.

Lipid materials are hydrophobic in nature and vulnerable to free radicals, especially to hydroxyl radicals $\left(\mathrm{OH}^{-}\right)$. This is because fatty acids do not possess enzymes that process its removal; besides, the very short half-life of free radicals makes them difficult to neutralize [49]. As shown in Figure 2, the three tested ${ }_{\mathrm{CA}}$ EO-SLN concentrations $(5,10$, and $20 \mu \mathrm{g} / \mathrm{mL})$ revealed antioxidant effects, minimizing the product formation derived from lipid peroxidation, such as the MDA (nmol MDA Eq/mL) respect to the negative control $(p<0.05)$. At concentrations of 5,10 , and $20 \mu \mathrm{g} / \mathrm{mL}$, the ${ }_{C A}$ EO-SLN showed $2.06 \pm 0.10,2.91 \pm 0.31$, and $1.99 \pm 0.47 \mathrm{nmol} \mathrm{MDA} \mathrm{Eq} / \mathrm{mL}$, respectively. Negative and positive controls were of $5.03 \pm 0.89$ and $0.21 \pm 0.01 \mathrm{nmol} \mathrm{MDA} \mathrm{Eq/mL}$, respectively. These results demonstrate the capacity of ${ }_{\mathrm{CA}} \mathrm{EO}-\mathrm{SLN}$ to inhibit Fenton reaction, which is based on the transfer of electrons between $\mathrm{Fe}^{++}$(acting as a homogeneous catalyst) and $\mathrm{H}_{2} \mathrm{O}_{2}$. Different authors have widely reported how 
DNA damage due to reactive oxygen species (ROS) can represent one major cause of cancer [50]. Terpenes (alpha-pinene) contained in essential oils may interact with toxic compounds and prevent DNA damage [4]. Neurodegenerative disorders, such as Alzheimer's disease and Parkinson's disease, are governed by disruption of cholinergic neurons and/or enhanced oxidative stress. The use of antioxidant phytochemicals such as terpenes has been proposed for the prevention and/or treatment of such disorders due to their capacity to strengthen the cholinergic function and antioxidant defence mechanisms. Lee et al. have reported the neuroprotective effect of alpha-pinene against learning and memory impairment induced by scopolamine in mice [51]. The essential oil from lemon peels, enriched with a cocktail of antioxidant phytochemicals (limonene, sabinene, alpha-pinene, neral, beta-pinene, linalool, 1,8-cineole, geranial, borneol, alpha-terpineol, terpinen-4-ol, linalyl acetate, and beta-caryophyllene), was also reported to inhibit key enzymes related to neurodegenerative conditions and pro-oxidant induced lipid peroxidation [52]. As reported by Elmann et al. (2009) [53], Salvia fruticosa's essential oil protected cultured primary brain astrocytes from $\mathrm{H}_{2} \mathrm{O}_{2}$-induced death. The neuroprotective effect of alpha-pinene against $\mathrm{H}_{2} \mathrm{O}_{2}$-induced oxidative stress was also confirmed in vitro in PC12 cells [54].

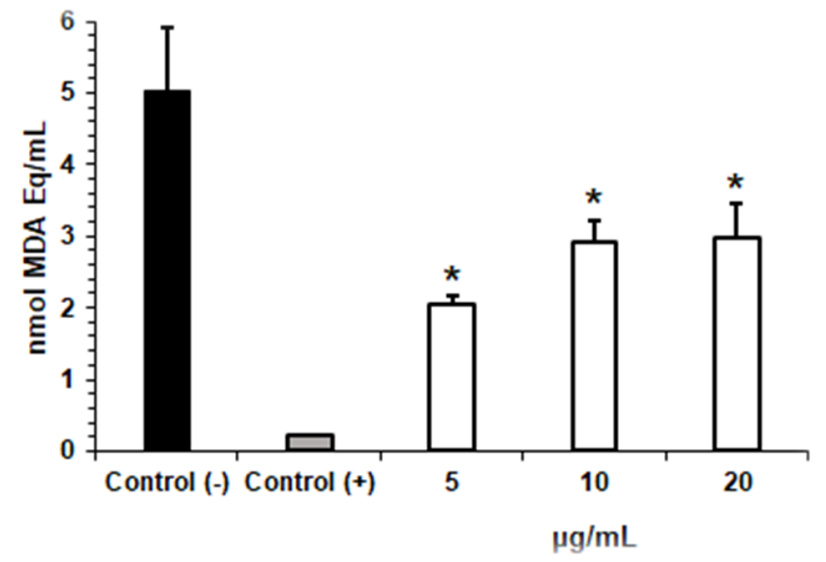

Figure 2. Effect of ${ }_{\mathrm{CA}} \mathrm{EO}-\mathrm{SLN}$ on the malondialdehyde equivalents (MDA Eq.) amount produced in the presence of $\mathrm{FeSO}_{4}$ (the free radical inducers). Analyses were carried out in triplicate. Trolox was utilized as the positive control and water as the negative control. Data are reported as mean \pm SEM. ${ }^{*} p<0.05$ respect to the negative one. One-way ANOVA followed by Bonferroni post-hoc test was applied.

The capacity of ${ }_{\mathrm{CA}} \mathrm{EO}-\mathrm{SLN}$ to capture free radicals, i.e., the antioxidant activity, was studied by DPPH assay and resulted to be concentration-dependent (Table 1). The DPPH values are indicators of antioxidant activity. For the positive control (BHT), 78.11\% scavenging of DPPH radical was observed at the highest tested concentration $(6.0 \mu \mathrm{g} / \mathrm{mL})$. Previous studies had reported similar results [55-57]. A linear regression of $R^{2}=0.9723$ was shown by plotting the data, and the $\mathrm{IC}_{50}$ was determined as $196.91 \mu \mathrm{g} / \mathrm{mL}$.

Table 1. Antioxidant activity (\% scavenging of free radical DPPH) of the Croton argyrophyllus Kunth' essential oil when loaded in cetyl palmitate SLN. Data are given as means \pm standard deviations (SD).

\begin{tabular}{cc}
\hline$\mu \mathrm{g} / \mathrm{mL}$ & \% Scavenging $\pm \mathrm{SD}$ \\
\hline 1 & $1.76 \pm 0.32$ \\
2 & $5.92 \pm 0.18$ \\
3 & $7.83 \pm 1.21$ \\
4 & $11.14 \pm 1.07$ \\
5 & $17.23 \pm 0.61$ \\
10 & $22.30 \pm 1.42$ \\
\hline
\end{tabular}


Our results confirm that ${ }_{\mathrm{CA}}$ EO-SLN kept the antioxidant defence mechanisms of the Croton argyrophyllus Kunth essential oil. To be used in neurodegenerative diseases, the developed ${ }_{\mathrm{CA}}$ EO-SLN should be non-toxic [58-60]. The cell viability testing was done in a neuroblastoma cell line using the MTT assay (Figure 3).

\section{CAEO-SLN}

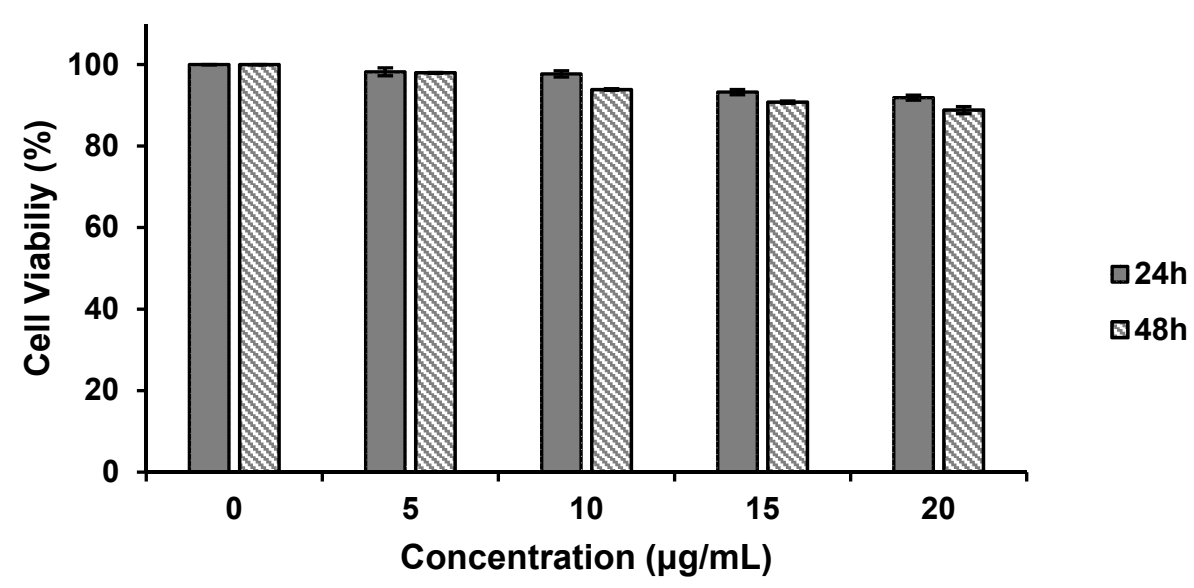

Figure 3. Study of the cytotoxic activity of the essential oil of Croton argyrophyllus leaves after the loading into SLN (CA EO-SLN), in SH-SY5Y cell line by the 3-(4,5-dimethyl-2-thiazolyl)-2,5-diphenyl2H-tetrazolium bromide (MTT) assay at 24 and $48 \mathrm{~h}$.

Due to its facility, sensitivity, and economy, the MTT assay is commonly used in screening tests by the US National Cancer Institute of the US [61], for the cytotoxicity assessment [62]. Previous studies have shown the cytotoxicity of essential oil of Croton argyrophyllus against all tumour cell lines, reporting $\mathrm{IC}_{50}$ below $30 \mu \mathrm{g} / \mathrm{mL}$ against SF-295 and OVCAR-8 cell lines after $72 \mathrm{~h}$ of incubation [63], which has been attributed to the combined effect of some of the bioactive compounds of the essential oil. The in vitro cytotoxic of Croton argyrophyllus Kunth essential oil showed IC50 values of $14.81 \mu \mathrm{g} / \mathrm{mL}$, $21.86 \mu \mathrm{g} / \mathrm{mL}$, and $32.79 \mu \mathrm{g} / \mathrm{mL}$ against SF-295, OVCAR-8, and MDA/MB-435, respectively, while against HCT-8 and HL-60, the IC50 values were above $50 \mu \mathrm{g} / \mathrm{mL}$ [55]. The cytotoxicity assay against SH-SY5Y cell line of essential oil has been tested after its loading into SLN, and values were kept above $70 \%$ cell viability, which indicates low risk of cytotoxicity [64]. The loading into cetyl palmitate SLN kept the cell viability up to $88.84 \pm 0.86 \%$. The modified release profile and the high encapsulation efficiency of the oil in the crystalline SLN matrix led to an improved cell resistance (89.63 $\pm 1.02 \%)$. The composition of lipid nanoparticles resembles the lipids of food and are known to have absorption enhancing effects when administered orally $[41,58,65-68]$. Besides, most of the cell lines tolerate lipid nanoparticle doses up to $1 \mathrm{mg} / \mathrm{mL}$, while only a few studies report cells surviving profiles higher than $1 \mathrm{mg} / \mathrm{mL}$ [58]. The highest SLN dose tested in our work was $20 \mu \mathrm{g} / \mathrm{mL}$, well below the cytotoxic range.

\section{Conclusions}

The essential oil obtained from Croton argyrophyllus Kunth has been loaded into cetyl palmitate solid lipid nanoparticles. The release profile of the oil from SLN followed the Korsemeyers-Peppas model; the nanoparticles kept the antioxidant activity (lipid peroxidation reduction and scavenging of free radicals) of the oil, with reduced cytotoxic effects in vitro against a neuroblastoma cell line (SH-SY5Y). It is therefore possible to postulate that the loading of essential oil of Croton into lipid nanoparticles can be an interesting approach in the formulation of novel functional foods with protective effects against neurodegenerative disorders and other chronic diseases associated to oxidative stress. 
Author Contributions: E.B.S., P.S., C.M., L.N.A., A.D., and M.L. have written the first draft and formatted the article. E.B.S., A.G.A., S.E.M., E.N., and A.S. have collaborated in the revision and editing of the second draft. E.B.S., P.S., C.M., L.N.A., A.D., M.L., A.G.A., S.E.M., and A.S. have contributed for the preparation of tables and figures. E.B.S., P.S., A.G.A., and A.S. have edited and supervised the data included in the review. E.B.S., P.S. and A.S. have conceptualized, structured, reviewed, and supervised the present manuscript. All authors made a substantial contribution to revise the work, and approved it for publication. All authors have read and agreed to the published version of the manuscript.

Funding: This research was supported by the Coordenação Aperfeiçoamento de Pessoal de Nivel Superior (CAPES), Fundação de Amparo à Pesquisa do Estado de Sergipe (FAPITEC) CHAMADA MS/CNPq/FAPITEC/SE/SES N 06/2018-PROGRAMA DE PESQUISA PARA O SUS: GESTÃO COMPARTILHADA EM SAÚDE-PPSUS SERGIPE 2017/2018, and Conselho Nacional de Desenvolvimento Científico e Tecnológico (CNPq). This research was also supported through the projects M-ERA-NET/0004/2015-PAIRED and UIDB/04469/2020 (strategic fund), receiving support from the Portuguese Science and Technology Foundation, Ministry of Science and Education (FCT/MEC) through national funds, and co-financed by FEDER, under the Partnership Agreement PT2020. The authors acknowledge the support of the research project: Nutraceutica come supporto nutrizionale nel paziente oncologico, CUP: B83D18000140007.

Conflicts of Interest: The authors declare no conflict of interest.

\section{References}

1. Wang, X.; Zhang, F.; Liu, Z.; Feng, H.; Yu, Z.B.; Lu, Y.; Zhai, H.; Bai, F.; Shi, Y.; Lan, M. Effects of essential oil from Croton tiglium L. on intestinal transit in mice. J. Ethnopharmacol. 2008, 117, 102-107. [CrossRef]

2. Compagnone, R.S.; Chavez, K.; Mateu, E.; Orsini, G.; Arvelo, F.; Suárez, A.I. Composition and cytotoxic activity of essential oils from Croton matourensis and Croton micans from Venezuela. Rec. Nat. Prod. 2010, 4, 101-108.

3. Du, Q.; Zhao, Y.; Liu, H.; Tang, C.; Zhang, M.; Ke, C.; Ye, Y. Isolation and Structure Characterization of Cytotoxic Phorbol Esters from the Seeds of Croton tiglium. Planta Med. 2017, 83, 1361-1367. [CrossRef] [PubMed]

4. Edris, A.E. Pharmaceutical and therapeutic potentials of essential oils and their individual volatile constituents: A review. Phytother. Res. 2007, 21, 308-323. [CrossRef]

5. Bakkali, F.; Averbeck, S.; Averbeck, D.; Idaomar, M. Biological effects of essential oils-A review. Food Chem. Toxicol. 2008, 46, 446-475. [CrossRef] [PubMed]

6. Cruz, R.C.D.; Silva, S.; Souza, I.A.; Gualberto, S.A.; Carvalho, K.S.; Santos, F.R.; Carvalho, M.G. Toxicological Evaluation of Essential Oil From the Leaves of Croton argyrophyllus (Euphorbiaceae) on Aedes aegypti (Diptera: Culicidae) and Mus musculus (Rodentia: Muridae). J. Med. Entomol. 2017, 54, 985-993. [CrossRef]

7. Silva-Filho, F.A.E.; Braz-Filho, R.; Silveira, E.R.; Lima, M.A.S. Structure elucidation of casbane diterpenes from Croton argyrophyllus. Magn. Reson. Chem. 2011, 49, 370-373. [CrossRef]

8. Péres, V.; Moura, D.; Sperotto, A.; Damasceno, F.; Caramão, E.; Zini, C.; Saffi, J. Chemical composition and cytotoxic, mutagenic and genotoxic activities of the essential oil from Pipergaudichaudianum Kunth leaves. Food Chem. Toxicol. 2009, 47, 2389-2395. [CrossRef]

9. Sylvestre, M.; Pichette, A.; Longtin, A.; Nagau, F.; Legault, J. Essential oil analysis and anticancer activity of leaf essential oil of Croton flavens L. from Guadeloupe. J. Ethnopharmacol. 2006, 103, 99-102. [CrossRef]

10. Santini, A.; Novellino, E. Nutraceuticals in hypercholesterolaemia: An overview. Br. J. Pharm. 2017, 174, 1450-1463. [CrossRef]

11. Salehi, B.; Venditti, A.; Sharifi-Rad, M.; Kregiel, D.; Sharifi-Rad, J.; Durazzo, A.; Lucarini, M.; Santini, A.; Souto, E.B.; Novellino, E.; et al. The Therapeutic Potential of Apigenin. Int. J. Mol. Sci. 2019, $20,1305$. [CrossRef] [PubMed]

12. Sun, Z.; Wang, H.; Wang, J.; Zhou, L.; Yang, P. Chemical composition and anti-inflammatory, cytotoxic and antioxidant activities of essential oil from leaves of Mentha piperita grown in China. PLoS ONE 2014, 9, e114767. [CrossRef] [PubMed]

13. Carvalho, A.A.; Andrade, L.N.; de Sousa, É.B.V.; de Sousa, D.P. Antitumor Phenylpropanoids Found in Essential Oils. Biomed Res. Int. 2015, 2015, 392674. [CrossRef] [PubMed]

14. Da Silva Brito, S.S.; Silva, F.; Malheiro, R.; Baptista, P.; Pereira, J.A. Croton argyrophyllus Kunth and Croton heliotropiifolius Kunth: Phytochemical characterization and bioactive properties. Ind. Crops Prod. 2018, 113, 308-315. [CrossRef] 
15. Ramos, J.M.O.; Santos, C.A.; Santana, D.G.; Santos, D.A.; Alves, P.B.; Thomazzi, S.M. Chemical constituents and potential antiinflammatory activity of the essential oil from the leaves of Croton argyrophyllus. Braz. J. Pharmacogn. 2013, 23, 644-650. [CrossRef]

16. De Araújo, S.S.; Aidar, F.J.; Matos, D.G.D.; Santos, J.L.D.; Souza, L.M.V.; Silva, A.N.D.; Dos Santos, R.M.; Marçal, A.C.; Mourão, D.M.; Júnior, A.L.; et al. Does Croton Argyrophyllus Extract Has an Effect on Muscle Damage and Lipid Peroxidation in Rats Submitted to High Intensity Strength Exercise? Int. J. Environ. Res. Public Health 2019, 16, 4237. [CrossRef]

17. Durazzo, A. Extractable and Non-extractable polyphenols: An overview. In Non-Extractable Polyphenols and Carotenoids: Importance in Human Nutrition and Health; Saura-Calixto, F., Pérez-Jiménez, J., Eds.; Royal Society of Chemistry: London, UK, 2018; pp. 1-37.

18. Durazzo, A.; Lucarini, M. Extractable and Non-Extractable Antioxidants. Molecules 2019, 24, 1933. [CrossRef]

19. Durazzo, A.; Lucarini, M. A Current shot and re-thinking of antioxidant research strategy. Braz. J. Anal. Chem. 2018, 5, 9-11. [CrossRef]

20. Yeung, A.W.K.; Tzvetkov, N.T.; El-Tawil, O.S.; Bungau, S.G.; Abdel-Daim, M.M.; Atanasov, A.G. Antioxidants: Scientific Literature Landscape Analysis. Oxidative Med. Cell. Longev. 2019, 8278454. [CrossRef]

21. Salehi, B.; Armstrong, L.; Rescigno, A.; Yeskaliyeva, B.; Seitimova, G.; Beyatli, A.; Sharmeen, J.; Mahomoodally, M.F.; Sharopov, F.; Durazzo, A.; et al. Lamium Plants-A Comprehensive Review on Health Benefits and Biological Activities. Molecules 2019, 24, 1913. [CrossRef]

22. Campos, J.R.; Severino, P.; Ferreira, C.S.; Zielinska, A.; Santini, A.; Souto, S.B.; Souto, E.B. Linseed Essential Oil-Source of Lipids as Active Ingredients for Pharmaceuticals and Nutraceuticals. Curr. Med. Chem. 2019, 26, 4537-4558. [CrossRef]

23. Matulyte, I.; Jekabsone, A.; Jankauskaite, L.; Zavistanaviciute, P.; Sakiene, V.; Bartkiene, E.; Ruzauskas, M.; Kopustinskiene, D.M.; Santini, A.; Bernatoniene, J. The Essential Oil and Hydrolats from Myristica fragrans Seeds with Magnesium Aluminometasilicate as Excipient: Antioxidant, Antibacterial, and Anti-inflammatory Activity. Foods 2020, 9, 37. [CrossRef] [PubMed]

24. Montesano, D.; Blasi, F.; Simonetti, M.S.; Santini, A.; Cossignani, L. Chemical and Nutritional Characterization of Seed Oil from Cucurbita maxima L. (var. Berrettina) Pumpkin. Foods 2018, 7, 30. [CrossRef]

25. Kiefer, J.; Lampe, A.I.; Nicoli, S.F.; Lucarini, M.; Durazzo, A. Identification of Passion Fruit Oil Adulteration by Chemometric Analysis of FTIR Spectra. Molecules 2019, 24, 3219. [CrossRef]

26. Dhifi, W.; Bellili, S.; Jazi, S.; Bahloul, N.; Mnif, W. Essential Oils' Chemical Characterization and Investigation of Some Biological Activities: A Critical Review. Medicines 2016, 3, 25. [CrossRef]

27. Ayaz, M.; Sadiq, A.; Junaid, M.; Ullah, F.; Subhan, F.; Ahmed, J. Neuroprotective and Anti-Aging Potentials of Essential Oils from Aromatic and Medicinal Plants. Front. Aging Neurosci. 2017, 9, 168. [CrossRef] [PubMed]

28. Zito, F.P.; Polese, B.; Vozzella, L.; Gala, A.; Genovese, D.; Verlezza, V.; Medugno, F.; Santini, A.; Barrea, L.; Cargiolli, M.; et al. Good adherence to mediterranean diet can prevent gastrointestinal symptoms: A survey from Southern Italy. World J. Gastrointest. Pharm. 2016, 7, 564-571. [CrossRef]

29. Aziz, Z.A.; Ahmad, A.; Setapar, S.H.M.; Karakucuk, A.; Azim, M.M.; Lokhat, D.; Ashraf, G.M. Essential Oils: Extraction Techniques, Pharmaceutical And Therapeutic Potential-A Review. Curr. Drug Metab. 2018, 19, 1100-1110. [CrossRef]

30. Valdivieso-Ugarte, M.; Gomez-Llorente, C.; Plaza-Díaz, J.; Gil, Á. Antimicrobial, Antioxidant, and Immunomodulatory Properties of Essential Oils: A Systematic Review. Nutrients 2019, 11, 2786. [CrossRef]

31. Souto, E.B.; Ribeiro, A.F.; Ferreira, M.I.; Teixeira, M.C.; Shimojo, A.A.M.; Soriano, J.L.; Naveros, B.C.; Durazzo, A.; Lucarini, M.; Souto, S.B.; et al. New Nanotechnologies for the Treatment and Repair of Skin Burns Infections. Int. J. Mol. Sci. 2020, 21, 393. [CrossRef] [PubMed]

32. Souto, E.B.; Souto, S.B.; Campos, J.R.; Severino, P.; Pashirova, T.N.; Zakharova, L.Y.; Silva, A.M.; Durazzo, A.; Lucarini, M.; Izzo, A.A.; et al. Nanoparticle Delivery Systems in the Treatment of Diabetes Complications. Molecules 2019, 24, 4209. [CrossRef]

33. Jose, S.; Anju, S.S.; Cinu, T.A.; Aleykutty, N.A.; Thomas, S.; Souto, E.B. In vivo pharmacokinetics and biodistribution of resveratrol-loaded solid lipid nanoparticles for brain delivery. Int. J. Pharm. 2014, 474, 6-13. [CrossRef]

34. Patel, M.; Souto, E.B.; Singh, K.K. Advances in brain drug targeting and delivery: Limitations and challenges of solid lipid nanoparticles. Expert Opin. Drug Deliv. 2013, 10, 889-905. [CrossRef] 
35. Martins, S.; Tho, I.; Reimold, I.; Fricker, G.; Souto, E.; Ferreira, D.; Brandl, M. Brain delivery of camptothecin by means of solid lipid nanoparticles: Formulation design, in vitro and in vivo studies. Int. J. Pharm. 2012, 439, 49-62. [CrossRef]

36. Martins, S.; Costa-Lima, S.; Carneiro, T.; Cordeiro-da-Silva, A.; Souto, E.B.; Ferreira, D.C. Solid lipid nanoparticles as intracellular drug transporters: An investigation of the uptake mechanism and pathway. Int. J. Pharm. 2012, 430, 216-227. [CrossRef]

37. Aditya, N.P.; Patankar, S.; Madhusudhan, B.; Murthy, R.S.; Souto, E.B. Arthemeter-loaded lipid nanoparticles produced by modified thin-film hydration: Pharmacokinetics, toxicological and in vivo anti-malarial activity. Eur. J. Pharm. Sci. 2010, 40, 448-455. [CrossRef]

38. Zielinska, A.; Martins-Gomes, C.; Ferreira, N.R.; Silva, A.M.; Nowak, I.; Souto, E.B. Anti-inflammatory and anti-cancer activity of citral: Optimization of citral-loaded solid lipid nanoparticles (SLN) using experimental factorial design and LUMiSizer(R). Int. J. Pharm. 2018, 553, 428-440. [CrossRef]

39. Zielinska, A.; Ferreira, N.R.; Durazzo, A.; Lucarini, M.; Cicero, N.; Mamouni, S.E.; Silva, A.M.; Nowak, I.; Santini, A.; Souto, E.B. Development and Optimization of Alpha-Pinene-Loaded Solid Lipid Nanoparticles (SLN) Using Experimental Factorial Design and Dispersion Analysis. Molecules 2019, 24, 2683. [CrossRef]

40. Zielińska, A.; Ferreira, N.R.; Feliczak-Guzik, A.; Nowak, I.; Souto, E.B. Loading, release profile and accelerated stability assessment of monoterpenes-loaded solid lipid nanoparticles (SLN). Pharm. Dev. Technol. 2020, 25, 832-844. [CrossRef]

41. Souto, E.B.; Muller, R.H. Lipid nanoparticles: Effect on bioavailability and pharmacokinetic changes. In Drug Delivery; Springer: Berlin/Heidelberg, Germany, 2010; pp. 115-141.

42. Souto, E.B.; Müller, R.H. SLN and NLC for topical delivery of ketoconazole. J. Microencapsul. 2005, 22, 501-510. [CrossRef]

43. Jose, S.; Fangueiro, J.F.; Smitha, J.; Cinu, T.A.; Chacko, A.J.; Premaletha, K.; Souto, E.B. Predictive modeling of insulin release profile from cross-linked chitosan microspheres. Eur. J. Med. Chem. 2013, 60, 249-253. [CrossRef]

44. Aksoy, L.; Kolay, E.; Ağılönü, Y.; Aslan, Z.; Kargı̆̆lu, M. Free radical scavenging activity, total phenolic content, total antioxidant status, and total oxidant status of endemic Thermopsis turcica. Saudi J. Biol. Sci. 2013, 20, 235-239. [CrossRef] [PubMed]

45. Fangueiro, J.F.; Andreani, T.; Egea, M.A.; Garcia, M.L.; Souto, S.B.; Silva, A.M.; Souto, E.B. Design of cationic lipid nanoparticles for ocular delivery: Development, characterization and cytotoxicity. Int. J. Pharm. 2014, 461, 64-73. [CrossRef] [PubMed]

46. Souto, E.B.; Anselmi, C.; Centini, M.; Muller, R.H. Preparation and characterization of n-dodecyl-ferulateloaded solid lipid nanoparticles (SLN). Int. J. Pharm. 2005, 295, 261-268. [CrossRef]

47. Jose, S.; Cinu, T.A.; Sebastian, R.; Shoja, M.H.; Aleykutty, N.A.; Durazzo, A.; Lucarini, M.; Santini, A.; Souto, E.B. Transferrin-Conjugated Docetaxel-PLGA Nanoparticles for Tumor Targeting: Influence on MCF-7 Cell Cycle. Polymers 2019, 11, 1905. [CrossRef] [PubMed]

48. Nita, L.E.; Chiriac, A.P.; Nistor, M. An in vitro release study of indomethacin from nanoparticles based on methyl methacrylate/glycidyl methacrylate copolymers. J. Mater. Sci. Mater. Med. 2010, 21, 3129-3140. [CrossRef] [PubMed]

49. Halliwell, B.; Gutteridge, J.M. [1] Role of free radicals and catalytic metal ions in human disease: An overview. Methods Enzymol. 1990, 186, 1-85.

50. Waris, G.; Ahsan, H. Reactive oxygen species: Role in the development of cancer and various chronic conditions. J. Carcinog. 2006, 5, 14. [CrossRef]

51. Lee, G.Y.; Lee, C.; Park, G.H.; Jang, J.H. Amelioration of Scopolamine-Induced Learning and Memory Impairment by alpha-Pinene in C57BL/6 Mice. Evid. Based Complement. Altern. Med. 2017, 2017, 4926815. [CrossRef]

52. Oboh, G.; Olasehinde, T.A.; Ademosun, A.O. Essential oil from lemon peels inhibit key enzymes linked to neurodegenerative conditions and pro-oxidant induced lipid peroxidation. J. Oleo Sci. 2014, 63, 373-381. [CrossRef]

53. Elmann, A.; Mordechay, S.; Rindner, M.; Larkov, O.; Elkabetz, M.; Ravid, U. Protective Effects of the Essential Oil of Salvia fruticosa and Its Constituents on Astrocytic Susceptibility to Hydrogen Peroxide-Induced Cell Death. J. Agric. Food Chem. 2009, 57, 6636-6641. [CrossRef] [PubMed] 
54. Porres-Martinez, M.; Gonzalez-Burgos, E.; Carretero, M.E.; Gomez-Serranillos, M.P. In vitro neuroprotective potential of the monoterpenes alpha-pinene and 1,8-cineole against $\mathrm{H} 2 \mathrm{O} 2$-induced oxidative stress in PC12 cells. Z. Nat. C J. Biosci. 2016, 71, 191-199. [CrossRef]

55. Amaral, R.; Andrade, L.; Severino, P.; De Araujo, S.; Santos, M.; Dias, A.; Moraes Filho, M.; Ó Pessoa, C.; Carvalho, A.; Thomazzi, S.; et al. Investigation of the Possible Antioxidant and Anticancer Effects of Croton argyrophyllus (Euphorbiaceae). Chem. Eng. Trans. 2018, 64, 253-258.

56. Souto, E.B.; Zielinska, A.; Souto, S.B.; Durazzo, A.; Lucarini, M.; Santini, A.; Silva, A.M.; Atanasov, A.G.; Marques, C.; Andrade, L.N.; et al. (+)-Limonene 1,2-epoxide-loaded SLN: Evaluation of drug release, antioxidant activity and cytotoxicity in HaCaT cell line. Int. J. Mol. Sci. 2020, 21, 1449. [CrossRef]

57. Souto, E.B.; Souto, S.B.; Zielinska, A.; Durazzo, A.; Lucarini, M.; Santini, A.; Horbańczuk, O.K.; Atanasov, A.G.; Marques, C.; Andrade, L.N.; et al. Perillaldehyde 1,2-epoxide loaded SLN-tailored mAb: Production, physicochemical characterization and in vitro cytotoxicity profile in MCF-7 cell lines. Pharmaceutics 2020, 12, 161. [CrossRef] [PubMed]

58. Doktorovova, S.; Kovacevic, A.B.; Garcia, M.L.; Souto, E.B. Preclinical safety of solid lipid nanoparticles and nanostructured lipid carriers: Current evidence from in vitro and in vivo evaluation. Eur. J. Pharm. Biopharm. 2016, 108, 235-252. [CrossRef]

59. Doktorovova, S.; Souto, E.B.; Silva, A.M. Nanotoxicology applied to solid lipid nanoparticles and nanostructured lipid carriers-A systematic review of in vitro data. Eur. J. Pharm. Biopharm. 2014, 87, 1-18. [CrossRef]

60. Doktorovova, S.; Silva, A.M.; Gaivao, I.; Souto, E.B.; Teixeira, J.P.; Martins-Lopes, P. Comet assay reveals no genotoxicity risk of cationic solid lipid nanoparticles. J. Appl. Toxicol. 2014, 34, 395-403. [CrossRef]

61. Skehan, P.; Storeng, R.; Scudiero, D.; Monks, A.; McMahon, J.; Vistica, D.; Warren, J.T.; Bokesch, H.; Kenney, S.; Boyd, M.R. New colorimetric cytotoxicity assay for anticancer-drug screening. J. Natl. Cancer Inst. 1990, 82, 1107-1112. [CrossRef]

62. Berry, P.E.; Hipp, A.L.; Wurdack, K.J.; Van Ee, B.; Riina, R. Molecular phylogenetics of the giant genus Croton and tribe Crotoneae (Euphorbiaceae sensu stricto) using ITS and trnL-trnF DNA sequence data. Am. J. Bot. 2005, 92, 1520-1534. [CrossRef]

63. Ferraz, R.P.; Cardoso, G.M.; da Silva, T.B.; Fontes, J.E.d.N.; Prata, A.P.d.N.; Carvalho, A.A.; Moraes, M.O.; Pessoa, C.; Costa, E.V.; Bezerra, D.P. Antitumour properties of the leaf essential oil of Xylopia frutescens Aubl.(Annonaceae). Food Chem. 2013, 141, 196-200. [CrossRef]

64. Cooperstein, M.A.; Canavan, H.E. Assessment of cytotoxicity of (N-isopropyl acrylamide) and Poly(N-isopropyl acrylamide)-coated surfaces. Biointerphases 2013, 8, 19. [CrossRef] [PubMed]

65. Aji Alex, M.R.; Chacko, A.J.; Jose, S.; Souto, E.B. Lopinavir loaded solid lipid nanoparticles (SLN) for intestinal lymphatic targeting. Eur. J. Pharm. Sci. 2011, 42, 11-18. [CrossRef] [PubMed]

66. Martins, S.; Silva, A.C.; Ferreira, D.C.; Souto, E.B. Improving oral absorption of Salmon calcitonin by trimyristin lipid nanoparticles. J. Biomed. Nanotechnol. 2009, 5, 76-83. [CrossRef] [PubMed]

67. Muller, R.H.; Runge, S.; Ravelli, V.; Mehnert, W.; Thunemann, A.F.; Souto, E.B. Oral bioavailability of cyclosporine: Solid lipid nanoparticles (SLN) versus drug nanocrystals. Int. J. Pharm. 2006, 317, 82-89. [CrossRef]

68. Muller, R.H.; Runge, S.A.; Ravelli, V.; Thunemann, A.F.; Mehnert, W.; Souto, E.B. Cyclosporine-loaded solid lipid nanoparticles (SLN): Drug-lipid physicochemical interactions and characterization of drug incorporation. Eur. J. Pharm. Biopharm. 2008, 68, 535-544. [CrossRef]

(C) 2020 by the authors. Licensee MDPI, Basel, Switzerland. This article is an open access article distributed under the terms and conditions of the Creative Commons Attribution (CC BY) license (http://creativecommons.org/licenses/by/4.0/). 